\title{
Comprehensive Income and Stock Return: Evidence from the Tokyo Stock Exchange
}

\author{
Chikashi Tsuji ${ }^{1}$ \\ ${ }^{1}$ Faculty of Economics, Chuo University, Tokyo, Japan \\ Correspondence: Chikashi Tsuji, Faculty of Economics, Chuo University, 742-1 Higashinakano Hachioji-shi, \\ Tokyo 192-0393, Japan. Tel: 81-42-674-2211. E-mail: mail_sec_low@minos.ocn.ne.jp
}

Received: March 22, 2013 Accepted: April 7, 2013 Online Published: July 3, 2013

doi:10.5539/jms.v3n3p142 URL: http://dx.doi.org/10.5539/jms.v3n3p142

\begin{abstract}
This paper examines whether the International Financial Reporting Standards (IFRS)' comprehensive income is related with the future performance of the firms listed on the Tokyo Stock Exchange (TSE) First Section. We find that in Japan, comprehensive income is not superior to other earnings or cash flow variables in predicting future equity returns of the TSE First Section firms. Instead, the ordinary profit to total asset ratio and the earnings before interest and tax to total asset ratio demonstrate the stronger predictive power for the future firm performance.
\end{abstract}

Keywords: comprehensive income, firm performance, panel data analysis

\section{Introduction}

Recently, many Japanese firms began to disclose comprehensive income data. Then does comprehensive income include useful information for investors in the Japanese capital markets? As to international markets, there are several papers that empirically examined on this matter. For instance, Biddle and Choi (2006) found that comprehensive income defined by Financial Accounting Standards Board (FASB) Statement 130 outperformed both traditional net income and fully comprehensive income in explaining the US stock returns. In addition, Chambers et al. (2007) demonstrated the evidence that in the US markets, other comprehensive income was priced in the post-Statement of Financial Accounting Standards (SFAS) 130 periods. Moreover, Dhaliwal et al. (1999) documented that there was no evidence that comprehensive income was strongly connected with the US stock returns. Furthermore, Kanagaretnam et al. (2009) revealed that in Canada, aggregate comprehensive income was more strongly related with both equity price and returns than net income. Other related studies are Hayn (1995), Hirst and Hopkins (1998), Jordan and Clark (2002), Francis et al. (2004), Mitra and Hossain (2009), Bamber et al. (2010), and Kabir and Laswad (2011), for example. However, as far as we know, there exists little empirical research on this issue by exploiting the Japanese data.

Based on these research backgrounds, the objective of this paper is to empirically test whether comprehensive income includes useful information for the future firm performance in the Tokyo Stock Exchange (TSE) First Section. The contributions of this study are as follows. First, we find that in the TSE First Section, comprehensive income is not superior to other earnings or cash flow variables in predicting the future firm performance. Second, our investigations also reveal that the ordinary profit to total asset ratio and the earnings before interest and tax (EBIT) to total asset ratio demonstrate the stronger predictive power for the future firm performance in Japan. The rest of the paper is organized as follows. Section 2 describes our data and methodology, Section 3 explains our empirical results, and Section 4 summarizes the paper.

\section{Data and Methodology}

We exploit the stacked data from the fiscal year of 2009 to 2011 and we use the pooled regressions in our empirical tests. This is because in Japan, the comprehensive income data disclosed by firms are well available after the fiscal year of 2009. In our regressions, dependent variable is the TSE First Section firm's six-month future stock return from the end of the each firm's fiscal year. Regarding the explanatory variables, OPP means the operating profit divided by total asset, ORP is the ordinary profit divided by total asset, and EBIT is the EBIT divided by total asset. Further, EBITDA is the earnings before interest, tax, depreciation and amortization (EBITDA) divided by total asset, OPCASH is the operating cash flow divided by total asset, NI is the net income 
divided by total asset, and COMP is the comprehensive income divided by total asset (Our comprehensive income is in accordance with the International Financial Reporting Standards (IFRS), and in our regressions, COMP is expressed as COMP ${ }^{\mathrm{IFRS}}$.). Moreover, in our regressions, we use four control variables: LNSIZE is the log natural of market capitalization, TANG is the tangible fixed asset divided by total asset, DEBT is the total debt divided by total asset, and LIQ is the short-term liquidity to current liability ratio. The data to construct all variables are supplied by the Quick Corp.

In our panel data analyses, we use three models. The first is the single accounting variable model including four control variables, namely it is the following pooled regression model (1):

$$
R E T_{i, t+6 m}=\eta_{0}+\eta_{1} X_{i, t}+\eta_{2} L N S I Z E_{i, t}+\eta_{3} T A N G_{i, t}+\eta_{4} D E B T_{i, t}+\eta_{5} L I Q_{i, t}+\pi_{i, t+6 m} .
$$

Where $X_{i, t}$ denotes the accounting variable, namely, OPP, ORP, EBIT, EBITDA, OPCASH, NI, or COMP.

Next, our second model is to compare the predictable power of comprehensive income and other earnings or cash flow variables for future stock returns. This is the following no control variable model:

$$
R E T_{i, t+6 m}=\zeta_{0}+\zeta_{1} X_{i, t}+\zeta_{2} C O M P_{i, t}^{I F R S}+\kappa_{i, t+6 m} .
$$

Where $X_{i, t}$ denotes the explanatory variable excluding COMP: OPP, ORP, EBIT, EBITDA, OPCASH, or NI.

Furthermore, we set the following pooled regression model (3) to compare the predictive power of comprehensive income and other accounting variables by including control variables:

$$
R E T_{i, t+6 m}=\xi_{0}+\xi_{1} X_{i, t}+\xi_{2} C O M P_{i, t}^{I F R S}+\xi_{3} L N S I Z E_{i, t}+\xi_{4} T A N G_{i, t}+\xi_{5} D E B T_{i, t}+\xi_{6} L I Q_{i, t}+\tau_{i, t+6 m} .
$$

Where $X_{i, t}$ is the same explanatory variable as in regression (2).

Table 1. Descriptive statistics for the analyzed variables of the firms listed on the Tokyo Stock Exchange First Section: balanced panel data for the fiscal year from 2009 to 2011

\begin{tabular}{lllllll}
\hline & RET & OPP & ORP & EBIT & EBITDA & OPCASH \\
\hline Mean & -10.618 & 5.876 & 5.860 & 6.358 & 10.915 & 8.316 \\
Median & -11.130 & 4.957 & 4.953 & 5.527 & 9.748 & 7.786 \\
Std. Dev. & 17.540 & 6.042 & 6.292 & 6.204 & 7.581 & 7.727 \\
Skewness & 0.711 & 1.062 & 0.819 & 0.865 & 1.128 & 1.020 \\
Kurtosis & 5.606 & 9.788 & 10.208 & 10.214 & 7.867 & 15.518 \\
Obs.(Stacked) & 3351 & 3351 & 3351 & 3351 & 3351 & 3351 \\
Obs.(CS) & 1117 & 1117 & 1117 & 1117 & 1117 & 1117 \\
\hline & NI & COMP & LNSIZE & TANG & DEBT & LIQ \\
\hline Mean & 2.658 & 2.708 & 3.902 & 24.090 & 48.973 & 104.537 \\
Median & 2.575 & 2.627 & 3.681 & 21.009 & 48.968 & 32.085 \\
Std. Dev. & 5.059 & 5.215 & 1.539 & 17.965 & 21.457 & 758.250 \\
Skewness & -1.216 & -0.943 & 0.601 & 1.107 & -0.070 & 24.955 \\
Kurtosis & 12.362 & 11.964 & 2.939 & 4.207 & 2.216 & 715.154 \\
Obs.(Stacked) & 3351 & 3351 & 3351 & 3351 & 3351 & 3351 \\
Obs.(CS) & 1117 & 1117 & 1117 & 1117 & 1117 & 1117 \\
\hline
\end{tabular}

Notes: This table shows the descriptive statistics for the analyzed variables as to the firms listed on the Tokyo Stock Exchange First Section. These data are balanced panel data for the period from the fiscal year of 2009 to 2011. In the table, first, RET denotes the six-month future return from the end of the fiscal year of each firm. In addition, OPP denotes the operating profit to total asset ratio, ORP denotes the ordinary profit to total asset ratio, and EBIT denotes the earnings before interest and tax to total asset ratio. Further, EBITDA is the earnings before interest, tax, depreciation and amortization to total asset ratio, OPCASH denotes the operating cash flow to total asset ratio, NI denotes the net income to total asset ratio, and COMP denotes the comprehensive income to total asset ratio. Our comprehensive income is in accordance with the International Financial Reporting Standards (IFRS), and in our regressions, COMP is expressed as COMP ${ }^{\mathrm{IFRS}}$. Moreover, LNSIZE is the log natural of market capitalization, TANG is the tangible fixed asset to total asset ratio, DEBT is the total debt to total asset ratio, and LIQ is the short-term liquidity to current liability ratio. Further, Std. Dev. is the standard deviations, Obs. (Stacked) is the pooled data number from the fiscal year of 2009 to 2011, and Obs. (CS) is the number of cross-sectional data in each year. 
Table 2. The relations between profits, cash flows, comprehensive income and six-month future stock returns of the firms of the TSE First Section: the results of the panel data analyses with control variables for the fiscal year from 2009 to 2011

\begin{tabular}{|c|c|c|c|c|c|c|c|}
\hline & Model 1 & Model 2 & Model 3 & Model 4 & Model 5 & Model 6 & Model 7 \\
\hline Const. & $-10.533 * * *$ & $-11.203 * * *$ & $-11.005 * * *$ & $-9.941 * * *$ & $-8.496 * * *$ & $-9.014 * * *$ & $-8.799 * * *$ \\
\hline$p$-value & 0.000 & 0.000 & 0.000 & 0.000 & 0.000 & 0.000 & 0.000 \\
\hline OPP & $0.625 * * *$ & & & & & & \\
\hline$p$-value & 0.000 & & & & & & \\
\hline ORP & & $0.635^{* * *}$ & & & & & \\
\hline$p$-value & & 0.000 & & & & & \\
\hline EBIT & & & $0.626^{* * *}$ & & & & \\
\hline$p$-value & & & 0.000 & & & & \\
\hline EBITDA & & & & $0.356^{* * *}$ & & & \\
\hline$p$-value & & & & 0.000 & & & \\
\hline OPCASH & & & & & $0.268 * * *$ & & \\
\hline$p$-value & & & & & 0.000 & & \\
\hline NI & & & & & & $0.628^{* * *}$ & \\
\hline$p$-value & & & & & & 0.000 & \\
\hline COMP & & & & & & & $0.570 * * *$ \\
\hline$p$-value & & & & & & & 0.000 \\
\hline LNSIZE & $-0.927 * * *$ & $-0.974 * * *$ & $-0.963 * * *$ & $-0.851 * * *$ & $-0.613 * * *$ & $-0.749 * * *$ & $-0.698 * * *$ \\
\hline$p$-value & 0.000 & 0.000 & 0.000 & 0.000 & 0.000 & 0.000 & 0.000 \\
\hline TANG & $0.056^{* * *}$ & $0.058 * * *$ & $0.056^{* * *}$ & $0.047 * * *$ & $0.041 * * *$ & $0.059 * * *$ & $0.056^{* * *}$ \\
\hline$p$-value & 0.000 & 0.000 & 0.000 & 0.000 & 0.000 & 0.000 & 0.000 \\
\hline DEBT & $-0.029 * * *$ & $-0.014 * *$ & $-0.023^{* * *}$ & $-0.046^{* * *}$ & $-0.059^{* * *}$ & $-0.037 * * *$ & $-0.042 * * *$ \\
\hline$p$-value & 0.000 & 0.044 & 0.001 & 0.000 & 0.000 & 0.000 & 0.000 \\
\hline LIQ & 0.0002 & 0.0001 & 0.0001 & $0.0003^{*}$ & $8.77 \mathrm{E}-05$ & $0.0003^{* * *}$ & $0.0003 * *$ \\
\hline$p$-value & 0.157 & 0.395 & 0.458 & 0.062 & 0.669 & 0.005 & 0.018 \\
\hline $\operatorname{Adj} . R^{2}$ & 0.197 & 0.217 & 0.217 & 0.108 & 0.077 & 0.111 & 0.101 \\
\hline Obs. & 3351 & 3351 & 3351 & 3351 & 3351 & 3351 & 3351 \\
\hline
\end{tabular}

Notes: This table shows the results of the panel data analyses for the fiscal year from 2009 to 2011. In this table, the dependent variable is the TSE First Section firm's six-month future return from the end of the fiscal year of each firm. With respect to the explanatory variables, OPP denotes the operating profit to total asset ratio, ORP denotes the ordinary profit to total asset ratio, and EBIT denotes the earnings before interest and tax to total asset ratio. Further, EBITDA denotes the earnings before interest, tax, depreciation and amortization to total asset ratio, OPCASH denotes the operating cash flow to total asset ratio, NI denotes the net income to total asset ratio, and COMP denotes the comprehensive income to total asset ratio. Our comprehensive income is in accordance with the International Financial Reporting Standards (IFRS), and in our regressions, COMP is expressed as COMP ${ }^{\mathrm{IFRS}}$ Moreover, we employ four control variables in regressions: LNSIZE denotes the log natural of market capitalization, TANG denotes the tangible fixed asset to total asset ratio, DEBT denotes the total debt to total asset ratio, and LIQ denotes the short-term liquidity to current liability ratio. In addition, Const. in this table means the constant term of regressions. Further, Obs. means the number of panel data sample and $A d j . R^{2}$ is the adjusted $R$-squared value. Moreover, ${ }^{* * *}$ denotes the statistical significance of the coefficients at the $1 \%$ level, ** denotes the statistical significance of the coefficients at the $5 \%$ level, and * denotes the statistical significance of the coefficients at the $10 \%$ level, respectively. 
Table 3. The comparisons of the explanatory power for six-month future stock returns of several accounting variables and comprehensive income of the TSE First Section firms: the results of the panel data analyses without control variables for the fiscal year from 2009 to 2011

\begin{tabular}{lllllll}
\hline & Model 1 & Model 2 & Model 3 & Model 4 & Model 5 & Model 6 \\
\hline Const. & $-13.746^{* * *}$ & $-13.893^{* * *}$ & $-14.126^{* * *}$ & $-13.283^{* * *}$ & $-13.137^{* * *}$ & $-12.099^{* * *}$ \\
$p$-value & 0.000 & 0.000 & 0.000 & 0.000 & 0.000 & 0.000 \\
OPP & $0.554^{* * *}$ & & & & \\
$p$-value & 0.000 & & & & & \\
ORP & & $0.614^{* * *}$ & & & & \\
$p$-value & & 0.000 & & & & \\
EBIT & & & $0.594^{* * *}$ & & & \\
$p$-value & & 0.000 & & & \\
EBITDA & & & & $0.156^{* * *}$ & & \\
$p$-value & & & 0.000 & & \\
OPCASH & & & & & $0.156^{* * *}$ & \\
$p$-value & & & & & & 0.000 \\
NI & & & & & & 0.000 \\
$p$-value & & & & & & \\
COMP & 0.046 & -0.051 & -0.018 & $0.413^{* * * *}$ & $0.466^{* * *}$ & 0.060 \\
$p$-value & 0.370 & 0.290 & 0.716 & 0.000 & 0.000 & 0.494 \\
\hline$A d j . R^{2}$ & 0.146 & 0.166 & 0.157 & 0.085 & 0.136 & 0.071 \\
Obs. & 3351 & 3351 & 3351 & 3351 & 3351 & 3351 \\
\hline
\end{tabular}

Notes: This table shows the results of the panel data analyses for the fiscal year from 2009 to 2011. In this table, the dependent variable is the TSE First Section firm's six-month future return from the end of the fiscal year of each firm. With respect to the explanatory variables, OPP denotes the operating profit to total asset ratio, ORP denotes the ordinary profit to total asset ratio, and EBIT denotes the earnings before interest and tax to total asset ratio. Further, EBITDA denotes the earnings before interest, tax, depreciation and amortization to total asset ratio, OPCASH denotes the operating cash flow to total asset ratio, NI denotes the net income to total asset ratio, and COMP denotes the comprehensive income to total asset ratio. Our comprehensive income is in accordance with the International Financial Reporting Standards (IFRS), and in our regressions, COMP is expressed as COMP ${ }^{\mathrm{IFRS}}$ In addition, Const. in this table means the constant term of regressions. Further, Obs. means the number of stacked data sample and $\operatorname{Adj} . R^{2}$ is the adjusted $R$-squared value. Moreover, *** denotes the statistical significance of the coefficients at the $1 \%$ level, $* *$ denotes the statistical significance of the coefficients at the $5 \%$ level, and * denotes the statistical significance of the coefficients at the $10 \%$ level, respectively.

\section{Results of Pooled Regressions}

First, we exhibit the descriptive statistics for our employed variables of the TSE First Section firms in Table 1. These are the statistics as to the panel data for the fiscal year from 2009 to 2011 . From this table, we can overview their statistic characteristics. The numbers of stacked data are in cross-section, 1117, in time-series, 3 -years, and 3351 pooled data. Further, we show the results of our pooled regression (1) in Table 2, those of pooled regression (2) in Table 3, and those of pooled regression (3) in Table 4.

As to our empirical results, Table 2 firstly shows that comprehensive income does not exhibit the strong predictive power of the future six-month stock returns of the TSE First Section firms. We understand this from the adjusted $R$-squared values. Instead, ORP and EBIT show much stronger predictive power for the future returns. Second, Table 3 indicates that when we conduct one-to-one comparison between comprehensive income and other earnings or cash flow variables, comprehensive income is always dominated by other variables. This is judged by the results of our pooled regression (2). The exceptions are only the cases of EBITDA and OPCASH. Thirdly, Table 4 exhibits that even if we add four control variables; LNSIZE, TANG, DEBT, and LIQ, the results are almost the same. That is, the comprehensive income's predictive power for future stock returns in the TSE First Section firms is relatively weak and ORP and EBIT again demonstrate the strong and robust predictable power for the future TSE firms' performance. 
Table 4. The comparisons of the explanatory power for six-month future stock returns of several accounting variables and comprehensive income of the TSE First Section firms: The results of the panel data analyses with control variables for the fiscal year from 2009 to 2011

\begin{tabular}{|c|c|c|c|c|c|c|}
\hline & Model 1 & Model 2 & Model 3 & Model 4 & Model 5 & Model 6 \\
\hline Const. & $-10.485^{* * *}$ & $-11.247 * * *$ & $-11.005 * * *$ & $-9.890 * * *$ & $-9.202 * * *$ & $-9.008 * * *$ \\
\hline$p$-value & 0.000 & 0.000 & 0.000 & 0.000 & 0.000 & 0.000 \\
\hline OPP & $0.591 * * *$ & & & & & \\
\hline$p$-value & 0.000 & & & & & \\
\hline ORP & & $0.660 * * *$ & & & & \\
\hline$p$-value & & 0.000 & & & & \\
\hline EBIT & & & $0.634 * * *$ & & & \\
\hline$p$-value & & & 0.000 & & & \\
\hline EBITDA & & & & $0.188 * * *$ & & \\
\hline$p$-value & & & & 0.000 & & \\
\hline OPCASH & & & & & $0.142 * * *$ & \\
\hline$p$-value & & & & & 0.000 & \\
\hline NI & & & & & & $0.595 * * *$ \\
\hline$p$-value & & & & & & 0.000 \\
\hline COMP & 0.045 & -0.047 & -0.018 & $0.412 * * *$ & $0.498 * * *$ & 0.037 \\
\hline$p$-value & 0.368 & 0.293 & 0.702 & 0.000 & 0.000 & 0.687 \\
\hline LNSIZE & $-0.930 * * *$ & $-0.971 * * *$ & $-0.958^{* * *}$ & $-0.868^{* * *}$ & $-0.814 * * *$ & $-0.748 * * *$ \\
\hline$p$-value & 0.000 & 0.000 & 0.000 & 0.000 & 0.000 & 0.000 \\
\hline TANG & $0.054 * * *$ & $0.058 * * *$ & $0.054 * * *$ & $0.054 * * *$ & $0.051 * * *$ & $0.059 * * *$ \\
\hline$p$-value & 0.000 & 0.000 & 0.000 & 0.000 & 0.000 & 0.000 \\
\hline DEBT & $-0.027 * * *$ & $-0.014 *$ & $-0.023 * * *$ & $-0.036 * * *$ & $-0.039 * * *$ & $-0.037 * * *$ \\
\hline$p$-value & 0.000 & 0.059 & 0.001 & 0.000 & 0.000 & 0.000 \\
\hline LIQ & 0.0002 & 0.0001 & $9.92 \mathrm{E}-05$ & $0.0002 *$ & $3.75 \mathrm{E}-05$ & $0.0003 * * *$ \\
\hline$p$-value & 0.164 & 0.415 & 0.497 & 0.080 & 0.793 & 0.005 \\
\hline $\operatorname{Adj} . R^{2}$ & 0.195 & 0.216 & 0.212 & 0.123 & 0.118 & 0.110 \\
\hline Obs. & 3351 & 3351 & 3351 & 3351 & 3351 & 3351 \\
\hline
\end{tabular}

Notes: This table shows the results of the panel data analyses for the fiscal year from 2009 to 2011. In this table, the dependent variable is the TSE First Section firm's six-month future return from the end of the fiscal year of each firm. With respect to the explanatory variables, OPP denotes the operating profit to total asset ratio, ORP denotes the ordinary profit to total asset ratio, and EBIT denotes the earnings before interest and tax to total asset ratio. Further, EBITDA denotes the earnings before interest, tax, depreciation and amortization to total asset ratio, OPCASH denotes the operating cash flow to total asset ratio, NI denotes the net income to total asset ratio, and COMP denotes the comprehensive income to total asset ratio. Our comprehensive income is in accordance with the International Financial Reporting Standards (IFRS), and in our regressions, COMP is expressed as COMP ${ }^{\mathrm{IFRS}}$ Moreover, we employ four control variables in regressions: LNSIZE is the log natural of market capitalization, TANG is the tangible fixed asset to total asset ratio, DEBT is the total debt to total asset ratio, and LIQ is the short-term liquidity to current liability ratio. Further, Const. in this table is the constant term of regressions, Obs. means the number of sample, and $A d j . R^{2}$ is the adjusted $R$-squared value. ${ }^{* * *}$ denotes the statistical significance of the coefficients at the $1 \%$ level, $* *$ denotes the statistical significance of the coefficients at the $5 \%$ level, and * denotes the statistical significance of the coefficients at the $10 \%$ level, respectively.

\section{Summary and Conclusions}

This paper examined the information contents included in the IFRS comprehensive income for the future performance of the firms listed on the TSE First Section. We found that in the TSE, comprehensive income disclosed by firms was not superior to other earnings or cash flow variables in predicting their future equity returns. Instead, the ordinary profit to total asset ratio and EBIT to total asset ratio exhibited the stronger predictive power for the future firm performance in Japan. These clarifications are our most significant contributions in this paper. Moreover, our interpretation of this evidence is that investors do not always look at the bottom line of the profit and loss statements of the TSE firms because compared to operating profit and ordinary profit, not only comprehensive income but also net income exhibited weaker predicting power for the future TSE First Section firms' performance. 
Further, our investigations revealed that the EBITDA and the comprehensive income were simultaneously statistically significant in the single regression, and operating cash flow and comprehensive income were also simultaneously statistically significant in the same regression. We interpret the evidence that cash flow variables and comprehensive income include supplemental information each other in Japan. Furthermore, we consider that it is also interesting to conduct similar research by using international data set and this shall be one of our future tasks.

\section{Acknowledgements}

The author thanks the Japan Society for the Promotion of Science for their generous financial assistance for this research. Further, the author greatly thanks the kind invitation from the journal to write to this journal. Moreover, I also thank the Editor and anonymous referees for their kind comments to this paper.

\section{References}

Bamber, L. S., Jiang, J., Petroni, K. R., \& Wang. I. Y. (2010). Comprehensive Income: Who's Afraid of Performance Reporting? The Accounting Review, 85, 97-126. http://dx.doi.org/10.2308/accr.2010.85.1.97

Biddle, G. C., \& Choi, J. H. (2006). Is comprehensive income useful? Journal of Contemporary Accounting and Economics, 2, 1-32.

Chambers, D., Linsmeier, T. J., Shakespeare, C., \& Sougiannis, T. (2007). An evaluation of SFAS No.130 comprehensive income disclosures. Review of Accounting Studies, 12, 557-593. http://dx.doi.org/ $10.1007 / \mathrm{s} 11142-007-9043-2$

Dhaliwal, D., Subramanyam, K. R., \& Trezevant, R. (1999). Is comprehensive income superior to net income as a measure of firm performance? Journal of Accounting and Economics, 26, 43-67.

Francis, J., LaFond, R., Olsson, P. M., \& Schipper, K. (2004). Cost of equity and earnings attributes. The Accounting Review, 79, 967-1010.

Hayn, C. (1995). The information content of losses. Journal of Accounting and Economics, 20, 125-153. http://dx.doi.org/10.1016/0165-4101(95)00397-2

Hirst, D. E., \& Hopkins, P. E. (1998). Comprehensive income disclosures and analysts' valuation judgments. Journal of Accounting Research, 36, 47-75. http://dx.doi.org/10.2139/ssrn.63588

Jordan, C. E., \& Clark, S. J. (2002). Comprehensive income: How is it being reported and what are its effects? Journal of Applied Business Research, 18, 1-8.

Kabir, M. H., \& Laswad, F. (2011). Properties of net income and total comprehensive income: New Zealand evidence. Accounting Research Journal, 24, 268-289. http://dx.doi.org/10.1108/10309611111187000

Kanagaretnam, K., Mathieu, R., \& Shehata, M. (2009). Usefulness of comprehensive income reporting in

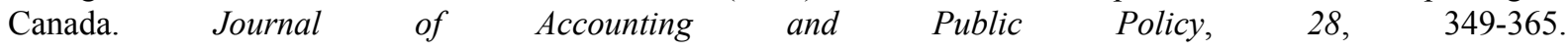
http://dx.doi.org/10.1016/j.jaccpubpol.2009.06.004

Mitra, S., \& Hossain, M. (2009). Value-relevance of pension transition adjustments and other comprehensive income components in the adoption year of SFAS No. 158. Review of Quantitative Finance and Accounting, 33, 279-301. http://dx.doi.org/10.1007/s11156-009-0112-4

\section{Copyrights}

Copyright for this article is retained by the author(s), with first publication rights granted to the journal.

This is an open-access article distributed under the terms and conditions of the Creative Commons Attribution license (http://creativecommons.org/licenses/by/3.0/). 